\title{
人間とロボットの協調搬送作業における最適な動作時間
}

\section{Identifining Optimum Movement Time for Generating Smooth Motion in Human-Robot Cooperative System}

\author{
$\bigcirc$ 相根 祥吾 (三重大) \\ Ahmad Faizal Bin Salleh（三重大院） \\ 正 池浦 良淳（三重大院） \\ 早川 \\ 聡一郎（三重大院） \\ 澤井 秀樹（三重大院）
}

Shogo AINE, Mie University, 1577 Kurimamachiya-cho, TsuCity,MiePrefecture, 514-0102, Japan

Ahmad Faizal Bin Salleh, Ryojun IKEURA, Soichiro HAYAKAWA and Hideki SAWAI, Graduate School of Mie University, 1577

Kurimamachiya-cho, TsuCity,MiePrefecture, 514-0102, Japan

Key Words: Minimum jerk model, Human-Robot cooperative system, Movement time, Traveled distance

\section{1.緒言}

現在、日本の社会問題の 1 つに少子高齢化があり、労働者 不足が懸念されている。その対策として、人と協調して物体 を運ぶことのできるロボットの開発があげられる。これまで、 人とロボットの協調搬送に関する研究は各種行われてきて いる。例えば、林原らはカセンサとアームの関節角の情報を 用いてロボットを制御することを提案した ${ }^{[1]}$ 。

我々は人どうしの協調搬送特性を用いて人とロボットの 滑らかな協調搬送作業の実現に向け研究している。まず、人 ごうしの協調搬送特性を調べた結果、搬送者が物体搬送距離 と搬送開始のタイミングを知る時、躍度最小軌道を生成し、 滑らかな協調動作を行うことが分かった ${ }^{[2]}$ 。躍度最小軌道の 生成のためには搬送時間と搬送距離の関係を調べる必要が あり、人どうしの協調搬送実験からその関係について調べた。 本稿では、人とロボットの協調搬送実験を行い、人どうし の協調搬送での搬送時間の有効性を調べたので報告する。

\section{2.人どうしの協調搬送実験}

躍度最小軌道でロボットを制御するために、まず人どうし にて協調搬送実験を行い、搬送時間と搬送距離の関係につい て調べた。図 1 は実験のイメージである。被験者は 2 人 1 組 のペアになり、5グループで実験を行う。物体を動かす距離 は、50mm,100mm,150mm,200mm の 4 つで、物体を動かす方向 は左右方向である。各方向各距離につき練習を 5 回行った後、 5 回データをとった。図 2 はモニターのイメージで、物体の現 在地と目標位置が示され、被験者はこれを見て物体搬送を行 う。図3 は左右方向の実験結果である。このグラフは時間と距 離の関係を表し、横軸は物体搬送距離を、縦軸は物体搬送時 間を示す。この結果からロボットの動作時間を設定する。

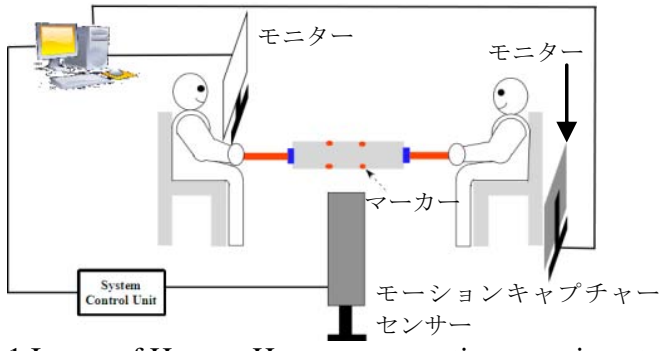

Fig. 1 Image of Human-Human cooperative experiment

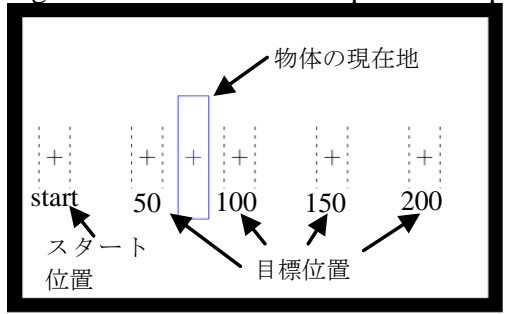

Fig.2 Image of monitor

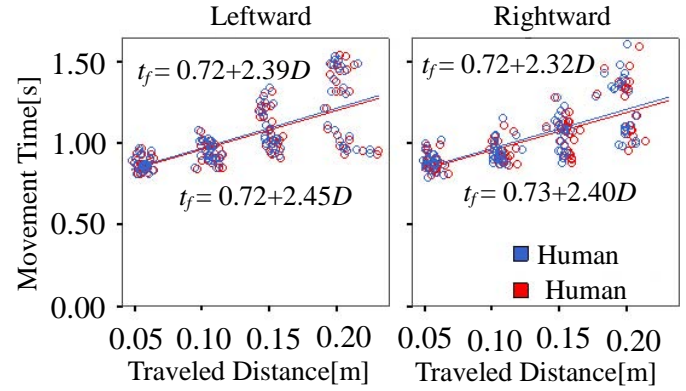

Fig.3 Result of Human-Human cooperative motion

\section{3.実験内容}

\section{1 実験装置}

図 4 に実験装置の構成を示す。実験で使用する搬送物体は 重さ約 $3 \mathrm{~kg}$ で両端は取手がついている。この物体には位置計 測用のマーカーが 4 つ取り付けられている。このマーカーの 位置は NDI 製 OptotrakCertusPositionSensor で計測され対象物 の位置と姿勢を計測すると同時に、被験者用のモニターに表 示される。

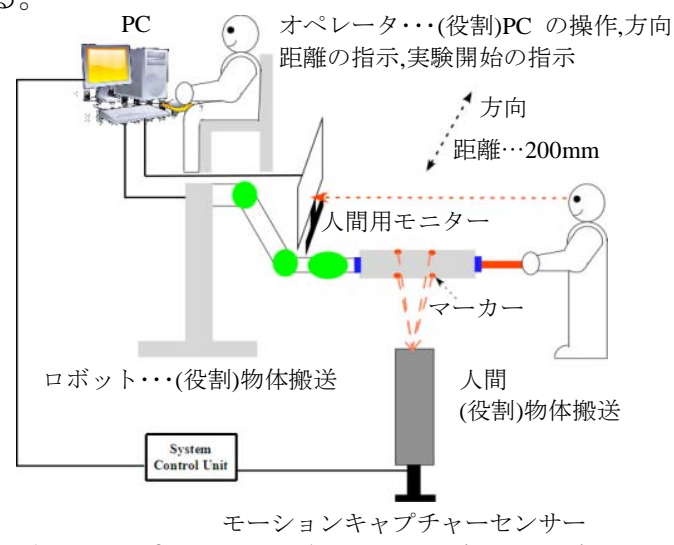

Fig.4 Image of Human-Robot cooperative experiment

\section{2 実験方法および条件}

本実験はオペレータと被験者の二人に役割を分担する。才 ペレータはPCの操作、距離と方向の指示、実験開始の合図 を出す。また、オペレータはロボットを起動させた際 5 カウ ント数え、その後にロボットが動き出す。被験者はロボット と協調して物体を指示された通りに運搬する。物体を動かす 距離は、 $200 \mathrm{~mm}$ で、方向は被験者から見て左,右の 2 方向で ある。

また、オペレータ 1 人、被験者 5 人で実験を行い、 5 つの グループに分けて実験を行う。調查の方法は一対比較法を用 いる。よって、2つの時間の組み合わせで 1 セットとする。 各方向につき練習を 2 回行った後、調査を開始する。被験者 には 1 セットごとにロボットの動作時間についてどちらがよ 
り自分の速度感に一致している動作時間かを評価してもら う。

\section{4.ロボットの動作時間}

ロボットの動作時間は人どうしの協調搬送から得られた 搬送時間を用いて実験を行う。これは、各方向各距離におけ る最大の時間と最小の時間を抽出し、その間に等間隔となる ように 3 つ時間を設定して、合計 5 つの時間を使って実験を 行う。この 5 つの時間は各方向・各距離において最大のもの から順に Max、MidMax、Ave、Midmin、Min という言葉に 置き換える。表 1 には左右方向の $200 \mathrm{~mm}$ の動作時間をまと める。図 5 は時間設定の例である。

ロボットは人どうしの協調搬送での踓度最小軌道で制御 する ${ }^{[3]}$ 。躍度最小軌道とは手先の動きを表すもので、次の式 で表される。

$$
x(t)=x_{0}+\left(x_{0}-x_{f}\right)\left(15 \tau^{4}-6 \tau^{5}-10 \tau^{3}\right)
$$

ここで、 $\tau=t / t f$ であり、 $x_{0}$ は $t=0$ での物体搬送開始位置、 $x_{f}$ は $t=t f$ での物体搬送終了位置である。ロボットを動か寸際に動 作時間が未知数なので、動作時間を入力することでロボット が動くようにする。

Table1 Robot movement times for $200 \mathrm{~mm}$ experiment

\begin{tabular}{|c|c|c|}
\hline \multirow{2}{*}{} & \multicolumn{2}{|c|}{ Movement times[s] } \\
\cline { 2 - 3 } & Leftward & Rightward \\
\hline Max & 1.538 & 1.658 \\
\hline MidMax & 1.374 & 1.434 \\
\hline Ave & 1.210 & 1.210 \\
\hline Midmin & 1.068 & 1.104 \\
\hline Min & 0.926 & 0.998 \\
\hline
\end{tabular}

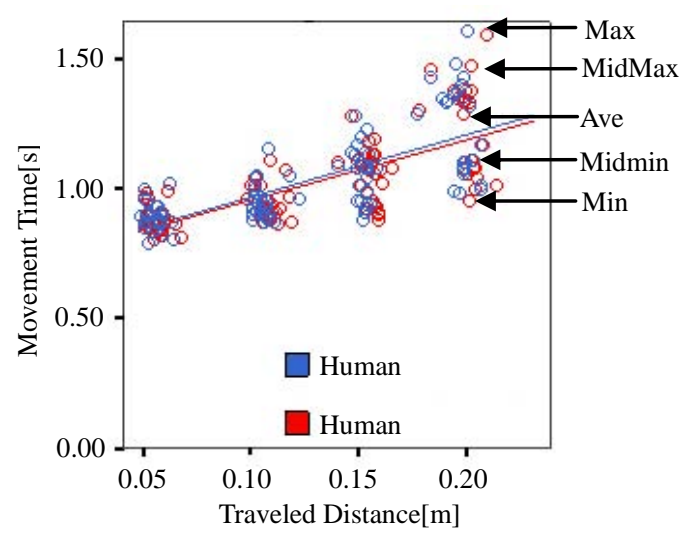

Fig.5 Example of time configuration

\section{5.実験結果と考察}

表 2 に左右方向の $200 \mathrm{~mm}$ での実験結果を示す。 5 人全て の結果をまとめた。表 $2(a)$ の 1 番上の行で左から 2 番目のマ スには 3 が書いてある。これは我々が定義した時間で Max とMidMax を比較した際にMax のほうがよいと答えた被験 者が 3 人いるということを示す。また、黒マスは実験を行わ なかったことを示す。

表 3 は先ほどの回答数を確率に直し、そこから標準正規分 布の逆関数をとった結果を示している。これは $\mathrm{z}$ 得点である。 また、Average は各動作時間の $\mathrm{z}$ 得点を横に足して平均をと った。この值を尺度值として評価し、一番大きい值を持つ動 作時間を最も良いものとする。表 3(a)より左方向 200mm で はMax、つまり最大の時間 $1.538 \mathrm{~s}$ が良いという結果となった。 また、表 3(b)より右方向 200mm では Ave、つまり中間に定 義されている時間 $1.210 \mathrm{~s}$ が良いという結果となった。

この結果より、次の疑問が生じる。なぜ左右方向の $200 \mathrm{~mm}$
で最も良いロボットの動作時間に違いが出るのか。この項目 について今後調査する予定である。

\section{6.結言}

本稿では左右方向の搬送距離 $200 \mathrm{~mm}$ での人とロボットの 協調搬送実験を行い、人どうしの協調搬送での搬送時間の有 効性を調べた。左方向では最大の時間、右方向では中間に定 義した時間が良いという結果が出た。

今後、左右方向の残りの距離、上下方向、前後方向の人と ロボットの協調搬送実験の調查結果をまとめる。また、左右 方向については動作時間の違いについて検証する。

Table2 Research frequency (overall) (a)Leftward

\begin{tabular}{|c|c|c|c|c|c|}
\hline & Max & MidMax & Ave & Midmin & Min \\
\hline Max & & 3 & 4 & 2 & 3 \\
\hline MidMax & 2 & & 3 & 4 & 2 \\
\hline Ave & 1 & 2 & & 3 & 3 \\
\hline Midmin & 3 & 1 & 2 & & 3 \\
\hline Min & 2 & 3 & 2 & 2 & \\
\hline
\end{tabular}

(b)Rightward

\begin{tabular}{|c|c|c|c|c|c|}
\hline & Max & MidMax & Ave & Midmin & Min \\
\hline Max & & 2 & 1 & 3 & 2 \\
\hline MidMax & 3 & & 2 & 3 & 4 \\
\hline Ave & 4 & 3 & & 3 & 4 \\
\hline Midmin & 2 & 2 & 2 & & 3 \\
\hline Min & 3 & 1 & 1 & 2 & \\
\hline
\end{tabular}

Table3 The $\mathrm{z}$ scores

(a)Leftward

\begin{tabular}{|c|c|c|c|c|c||c|}
\hline & Max & MidMax & Ave & Midmin & Min & Average \\
\hline Max & & 0.253 & 0.842 & -0.253 & 0.253 & $\mathbf{0 . 2 7 4}$ \\
\hline MidMax & -0.253 & & 0.253 & 0.842 & -0.253 & 0.147 \\
\hline Ave & -0.842 & -0.253 & & 0.253 & 0.253 & -0.147 \\
\hline Midmin & 0.253 & -0.842 & -0.253 & & 0.253 & -0.147 \\
\hline Min & -0.253 & 0.253 & -0.253 & -0.253 & & -0.127 \\
\hline
\end{tabular}
(b)Rightward

\begin{tabular}{|c|c|c|c|c|c||c|}
\hline & Max & MidMax & Ave & Midmin & Min & Average \\
\hline Max & & -0.253 & -0.842 & 0.253 & -0.253 & -0.274 \\
\hline MidMax & 0.253 & & -0.253 & 0.253 & 0.842 & 0.274 \\
\hline Ave & 0.842 & 0.253 & & 0.253 & 0.842 & $\mathbf{0 . 5 4 7}$ \\
\hline Midmin & -0.253 & -0.253 & -0.253 & & 0.253 & -0.127 \\
\hline Min & 0.253 & -0.842 & -0.842 & -0.253 & & -0.421 \\
\hline
\end{tabular}

\section{参考文献}

[1]林原靖男,園田幸伸,田窪朋仁,荒井裕彦,谷江和雄: 人とロボ ットによる長尺物の協調運搬(人の協調挙動に基づく鉛直 平面内の制御方法の検討), 日本機械学会論文集( $\mathrm{C}$ 編),67 巻,653 号,pp.162-169(2001)

[2]Shahriman ABU BAKAR,Ryojun IKEURA, Yuichiro HANDA,Takemi YANO,Kazuki MIZUTANI and Hideki SAWAI : Communication during the Cooperative Motion in the Task of Carrying an Object between Two Humans,Journal of Biomechanical Science and Engineering, Vol.5, No.2, pp.104-118(2010)

[3]TAMAR FLASH and NEVILLE HOGAN : The Coordination of Arm Movements:An Experimentally Confirmed Mathematical Model, The Journal of Neuroscience, Vol.5, No.7, pp.1688-1703(1985) 